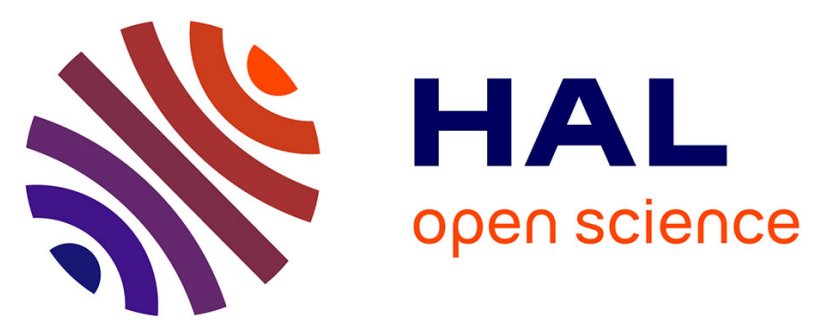

\title{
Effectiveness of golimumab in ulcerative colitis: A review of the real world evidence
}

Pablo Olivera, Silvio Danese, Lieven Pouillon, Stefanos Bonovas, Laurent Peyrin-Biroulet

\section{- To cite this version:}

Pablo Olivera, Silvio Danese, Lieven Pouillon, Stefanos Bonovas, Laurent Peyrin-Biroulet. Effectiveness of golimumab in ulcerative colitis: A review of the real world evidence. Digestive and Liver Disease, 2019, 51 (3), pp.327-334. 10.1016/j.dld.2018.11.002 . hal-03486332

\section{HAL Id: hal-03486332 https://hal.science/hal-03486332}

Submitted on 20 Dec 2021

HAL is a multi-disciplinary open access archive for the deposit and dissemination of scientific research documents, whether they are published or not. The documents may come from teaching and research institutions in France or abroad, or from public or private research centers.
L'archive ouverte pluridisciplinaire HAL, est destinée au dépôt et à la diffusion de documents scientifiques de niveau recherche, publiés ou non, émanant des établissements d'enseignement et de recherche français ou étrangers, des laboratoires publics ou privés.

\section{다)(1) $(5$}

Distributed under a Creative Commons Attribution - NonCommerciall 4.0 International 
Version of Record: https://www.sciencedirect.com/science/article/pii/S1590865818312210

Manuscript_49fa0f25d3b43db8a775e0ab4398561c

\section{Effectiveness of golimumab in ulcerative colitis: a review of the real}

\section{world evidence}

Pablo Olivera MD1; Silvio Danese MD, PhD²,3; Lieven Pouillon, MD,5; Stefanos Bonovas MD, PhD ${ }^{2,3}$; Laurent Peyrin-Biroulet MD, $\mathrm{PhD}^{4}$

${ }^{1}$ Gastroenterology Section, Department of Internal Medicine, Centro de Educación Médica e Investigaciones Clínicas (CEMIC), Buenos Aires, Argentina.

${ }^{2}$ Department of Biomedical Sciences, Humanitas University, Milan, Italy.

${ }^{3}$ IBD Center, Department of Gastroenterology, Humanitas Clinical and Research Center, Milan, Italy. ${ }^{4}$ INSERM U954 and Department of Hepatogastroenterology, Nancy University Hospital, Université de Lorraine, Vandoeuvre-lès-Nancy, France.

${ }^{5}$ Imelda GI Clinical Research Centre, Imeldaziekenhuis Bonheiden, Bonheiden, Belgium.

\section{Correspondence:}

Prof. Laurent Peyrin-Biroulet, MD, PhD

INSERM U954 and Department of Hepatogastroenterology, Nancy University Hospital, Lorraine

University, Allée du Morvan, F-54511 Vandoeuvre-lès-Nancy, France

Phone: + 33383 153631; Fax: + 33383153633

E-mail: peyrinbiroulet@gmail.com

Word count: 4247

(C) 2018 published by Elsevier. This manuscript is made available under the CC BY NC user license https://creativecommons.org/licenses/by-nc/4.0/ 


\section{$\underline{\text { Abstract }}$}

Background: Biologics against tumor necrosis factor (anti-TNF) have dramatically changed the management of moderate-to-severe ulcerative colitis (UC). In pivotal clinical trials, golimumab showed efficacy as induction and maintenance therapy in anti-TNF naïve UC patients. However, confirmatory data on effectiveness in the real world setting are needed.

Aim: to summarize recent evidence on the effectiveness of golimumab in observational real-world studies.

Methods: A literature search was conducted using Medline, Embase, and congresses databases for English language articles or abstracts on the effectiveness of golimumab published between January 1, 2014 and May 15, 2018. Pooled short-term (6 to 14 weeks) and mid- and long-term (24 to 54 weeks) clinical response and remission rates were calculated.

Results: 24 abstracts were included; of those 8 were published full-text articles and 16 were abstracts from medical conferences. Overall, pooled short-term clinical response and remission rates were $59.3 \%$ (range 35-85.5\%; 13 studies; 1429 patients) and 35.9\% (range 14-51.7\%; 9 studies; 666 patients), respectively. Pooled mid- and long-term clinical response and remission rates were 60.3\% (range 37.189.5\%; 4 studies; 356 patients) and 39.2\% (range 12-84\%; 8 studies; 822 patients), respectively.

Conclusions: Results of observational studies confirm that golimumab is an effective therapy for UC in clinical practice.

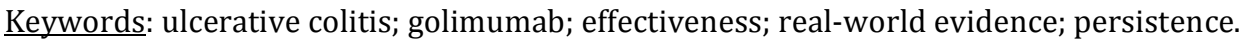


Introduction

Ulcerative colitis (UC) is one of the main forms of inflammatory bowel disease (IBD). It is a chronic disorder in which inflammation starts in the rectum and can extend proximally to the colon in various extents.[1] Clinically, patients can experience rectal bleeding, bloody diarrhea, abdominal pain, urgency and tenesmus, and it is characterized by periods of flare and remission. UC may present at any age, although the peak age of disease onset is between the third and fourth decade of life.[2] Given that UC affects mainly patients in working age, it can produce a detrimental effect in work productivity and quality of life.[3] Prevalence varies widely between geographical regions, with higher rates in North America and Europe (ranging from 43 to 505 per 100000), although incidence and prevalence are also increasing steeply in newly industrialized countries.[4] Treatment goals have recently shifted from merely symptomatic control to more objective targets, namely mucosal and histologic healing, which are associated with better disease outcomes.[5,6] Treatment options include conventional therapies, such as oral and rectal 5-aminosalycilate (5-ASA) compounds, thiopurines and corticosteroids. Biologics against tumor necrosis factor (anti-TNF) have been introduced for the treatment of moderate-to-severe UC in the past decades, and changed dramatically the disease management, not only by allowing mucosal healing in a significant number of patients, but also by reducing trends in colectomy rates and hospitalizations.[7] Currently, there are three anti-TNF agents approved for the treatment of UC: infliximab, adalimumab, and, more recently, golimumab.

Golimumab is a fully human IgG1 kappa monoclonal anti-TNF antibody, approved for the treatment of rheumatoid arthritis,[8] psoriatic arthritis,[9] ankylosing spondylitis,[10] and juvenile idiopathic arthritis.[11] In the phase 3 studies from the PURSUIT program, golimumab also demonstrated efficacy to induce and maintain clinical remission, as well as to induce mucosal healing, in moderately-to-severely active UC.[12,13] Although the results of these pivotal trials supported the benefit of golimumab in UC, confirmatory data on effectiveness in the real world setting remained eagerly needed, since patients enrolled in clinical trials frequently are not completely representative of those seen in routine clinical practice. In addition, the PURSUIT trials only included biologic naïve patients, and the utility of golimumab in the biologic experienced population remained to be defined in the clinical setting.

The aim of this review is to summarize recent evidence on the effectiveness of golimumab in the real world setting. 


\section{Methods}

A literature search was conducted using Medline and Embase for English language articles on the effectiveness of golimumab published between January 1, 2014 and May 15, 2018. We also reviewed the European Crohn's and Colitis Organization (ECCO) Congress (2014-2018), the United European Gastroenterology (UEG) Week Congress (2014-2018), the Digestive Disease Week (DDW) Congress (2016-2018) and the Italian Federation of Societies of Digestive Diseases (FISMAD) Congress (20162018) annual congresses databases. The search terms included the disease of interest "ulcerative colitis" and "inflammatory bowel disease", outcomes "effectiveness", "persistence", "efficacy" and context "realworld", "real-life" and "clinical practice".

Pooled short-term (6 to 14 weeks) and mid- and long-term (24 to 54 weeks) clinical response and remission rates were calculated.

\section{Literature search results}

After literature search 24 abstracts were included; of those 8 were published full-text articles and the 16 were abstracts from medical conferences. Sixteen studies evaluated short-term clinical outcomes (up to week 14), which included a total of 1471 patients (range 21-335). Mid-term and long-term clinical outcomes were evaluated in 10 studies, which included a total of 1055 patients (range 20-335). Objective measures of inflammation [C-reactive protein (CRP) and/or fecal calprotectin and/or mucosal healing] were assessed in 10 studies, which included a total of 687 patients (range 20-190) (Table 1).

\section{$\underline{\text { Real world prospective studies }}$}

In a prospective cohort study, Bosca-Watts et al evaluated short-term effectiveness of golimumab in 33 consecutive UC patients.[14] They describe a clinical response rate of $69.7 \%$ at week 14 , and steroid-free clinical remission of 51.5\%. Being anti-TNF naïve was the only independent factor associated with response at week 14.[14] Objective measures of inflammation were also assessed, with a decrease in mean fecal calprotectin value from $300 \mathrm{ug} / \mathrm{g}$ at baseline to $170.5 \mathrm{ug} / \mathrm{g}$ at week 14; mean CRP levels decreased from $11.9 \mathrm{mg} / \mathrm{L}$ at baseline to $3.4 \mathrm{mg} / \mathrm{L}$ at week 14.[14]

Detrez et al also evaluated prospectively the short-term effectiveness of golimumab in 21 patients with moderately-to-severely active UC.[15] Overall, clinical response at week 14 was seen in 48\% of patients, 
whereas clinical remission was achieved in 14\%. Mucosal healing was present in $28 \%$ of patients. Previous exposure to other anti-TNF agents negatively affected response rates, with a response rate of $64 \%$ in anti-TNF naïve patients, and 30\% in anti-TNF experienced patients. Notably, serum golimumab and anti-golimumab antibodies assays were developed. Serum golimumab concentrations were significantly higher in responders versus non-responders.[15]

Renna et al reported a series of 40 patients with moderate to severe UC treated with adalimumab $(n=21)$ and golimumab (n=19).[16] At week 8, there were no statistically significant differences between both groups in clinical remission (golimumab 31.5\% versus adalimumab 43\%, p=0.46). When stratified according to previous anti-TNF exposure, there were again no statistically significant differences (golimumab naïve $40 \%$ versus adalimumab naïve $50 \%$, p=0.7; golimumab non-naïve $28 \%$ versus adalimumab non-naïve 28\%). After univariate analysis, older age was the only factor associated with a higher 8-week clinical remission rate.[16]

In a multicenter prospective study, Tursi et al enrolled 93 consecutive UC patients who received golimumab.[17] At 6 months, clinical response was achieved in $64.5 \%$ of patients, and clinical remission in $36.5 \%$, but only $53 \%$ of those patients reached corticosteroid-free remission. Regarding objective measures of inflammation, mucosal healing was obtained in $19.3 \%$ of patients, and CRP and fecal calprotectin both decreased significantly during follow-up ( $\mathrm{p}<0.001)$.[17] A large multicenter prospective study from 21 centers in southern Italy included 190 UC patients treated with golimumab, 66\% of whom were anti-TNF naïve and 142 completed at least 3 months of treatment.[18] Three-month clinical response and clinical remission were $60 \%$ and 39\%, respectively. Mucosal healing was achieved in 53\% of patients. Complete discontinuation of corticosteroids was seen in $79 \%$ of responders. After multivariate analysis, factors associated with response were anti-TNF naïve status and total Mayo Score at initiation of therapy.[18]

In a study carried out in all centers from Sicily, Italy, the real-life effectiveness of different biologic therapies in IBD was evaluated.[19] Three hundred and thirty-five UC patients were included, with higher proportion of biologic-naïve patients among those who received infliximab versus those who received golimumab and adalimumab (91.6\% vs. $44.1 \%$ vs. $55.4 \%, \mathrm{p}<0.001)$. At week 12, clinical response or remission was higher for infliximab compared with golimumab (71.8\% vs. 56.6\%, p=0.034), but this difference was lost when patients were stratified in biologic-naïve and biologic-experienced. At week 52, clinical response or remission rate was higher for infliximab compared to golimumab (58.2\% vs. $38.2 \%$, 
$\mathrm{p}=0.039$ ) and adalimumab (58.2\% vs. 33.9\%, $\mathrm{p}=0.002)$, although this difference was significant only in biologic-naïve patients.[19]

Orlandini et al presented a cohort study that included 59 UC patients treated at two centers in central Italy; approximately half of them were anti-TNF experienced.[20] At week 12, 48\% of patients presented clinical response, with no significant difference between anti-TNF naïve and experienced groups. Median duration of treatment with golimumab was 7 months (IQR 4 -14).[20]

Berends et al presented a prospective study carried out in the Netherlands that evaluated effectiveness of golimumab in moderate-to-severe UC in a real life setting.[21] Twenty patients were enrolled; short-term (between week 8 and 10) endoscopic response was seen in 63\% of them. After 54 weeks, almost half of the patients lost clinical response during maintenance therapy after a median of 18 weeks. The other half of the patients continued treatment with golimumab after 1 year, and clinical remission was achieved in $66 \%$ of them, whereas endoscopic remission was seen in $60 \% \cdot[21]$

Armuzzi et al recently reported an interim analysis of a prospective multicenter study on the short and long-term effectiveness and impact on quality of life of golimumab in UC.[22] They included 83 and 38 patients who completed 8 and 32 weeks of treatment, respectively. Less than one third were anti-TNF experienced, and most of them had moderate disease activity. At week $32,89.5 \%$ were in sustained clinical response and $84.2 \%$ were in clinical remission.[22] Additionally, significant increases in the inflammatory bowel disease questionnaire (IBDQ) scores from baseline to week 8 and week 32 were seen, as well as a significant decrease in median CRP levels.[22] Concomitant treatment with oral 5-ASA was associated with significant improvement in quality of life. Similarly, in an interim analysis of a German prospective study evaluating work productivity and quality of life of 203 golimumab-treated UC patients,, significant improvements in all WPAI (work productivity activity impairment questionnaire) subscores and IBDQ scores were seen after 12 months.[23]

Eriksson et al recently reported an interim analysis of a prospective cohort study from Sweden, evaluating the effectiveness of golimumab in the real-life setting.[24] Fifty patients were included, most of them (70\%) being anti-TNF experienced. At week 12, 74\% were still on treatment with golimumab, and clinical response and clinical remission were seen in 35\% and 22\% of them, respectively. Median fecal calprotectin levels showed a significant decrease compared with baseline $(710 \mathrm{ug} / \mathrm{g}$ to $390 \mathrm{ug} / \mathrm{g}$ at week 12, $\mathrm{p}=0.02)$. Quality of life, as measured by the short health scale score, was also significantly improved compared with baseline.[24] 
In a single-center, prospective study, Girardin et al evaluated effectiveness of golimumab in 34 consecutive UC patients.[25] After induction, clinical response was achieved in 58\% of patients, with a significantly higher rate in patients who were anti-TNF naïve or previously intolerant to other anti-TNF. Moreover, after induction, a decrease in median fecal calprotectin level was seen in these clinical responders. After 6 months of treatment, 44\% (15/34) of patients were still in clinical remission.[25]

Overall, in these prospective studies, golimumab was efficacious for inducing short-term clinical response and remission in 53.8\% (range 35-69.7\%) and 31.6\% (range 14-51.7\%) of patients, respectively. Midand long-term clinical response and remission rates were 60\% (range $50-89.5 \%$ ) and $45.3 \%$ (range 30 $84 \%)$, respectively.

\section{$\underline{\text { Real world retrospective studies }}$}

In a small retrospective study including 23 UC patients, Castro-Laria et al described their initial experience with golimumab.[26] After a mean duration of treatment of 14.3 weeks (range 3-36 months), clinical response was seen in $85.5 \%$ and $75 \%$ of anti-TNF naïve and experienced patients, respectively. Corticosteroid withdrawal was possible in $74 \%$ of cases.[26]

In a large multicenter retrospective study, Taxonera et al evaluated 142 patients with moderate-to-severe UC under golimumab.[27] At week 8, clinical response and clinical remission rates were $65 \%$ and $32 \%$, respectively. Response rate for golimumab varied according to the line of therapy: $75 \%$ as first line antiTNF agent, $70 \%$ as second-line, and $50 \%$ as third-line ( $\mathrm{p}=0.007)$. After a median follow-up of 12 months, $57.7 \%$ maintained sustained clinical benefit, and $42.2 \%$ had golimumab failure, defined as discontinuation of the drug due to intolerance or absence/loss of response).[27]

O'Connell et al reported a large retrospective real-world study evaluating effectiveness and safety of golimumab as induction and maintenance therapy for UC in six centers in Ireland.[28] Seventy-two consecutive patients were included, $64 \%$ of them were anti-TNF naïve. The clinical response rate at month 3 and the corticosteroid-free clinical remission at month 6 were $55 \%$ and 39\%, respectively. Median time to golimumab discontinuation was 18.7 months (CI95\% 9.2-28.1). A CRP-level higher than 5 $\mathrm{mg} / \mathrm{l}$ at baseline was associated with failure to achieve 6-month corticosteroid-free remission and a shorter time to golimumab discontinuation.[28]

In a large retrospective nationwide cohort from Canada, Bressler et al evaluated treatment persistence of golimumab in 136 UC patients.[29] After 1 year, persistence rate of golimumab was 63\%, and the median 
time to golimumab discontinuation was 530 days, with no significant differences between anti-TNF naïve and experienced patients (550 versus 530 days, $\mathrm{p}>0.05)$.[29]

Biscaglia et al evaluated treatment persistence and efficacy of golimumab in a retrospective multicenter cohort study across 8 different Italian centers.[30] One hundred seventy-two UC patients were included, with approximately half of them being biologic-naïve. Median time-to-discontinuation was 15 months, and clinical efficacy was seen in $52 \%$ of patients at week 12 . After multivariate analysis, variables associated with treatment persistence were lower Mayo endoscopic score at baseline (OR 0.62, CI95\% 0.52-0.76, p<0.001), and the absence of previous exposure to infliximab (OR 0.41, CI95\% 0.20-0.86, $\mathrm{p}=0.01) \cdot[30]$

A single center study from Italy, evaluated corticosteroid-free clinical remission in UC patients treated with infliximab $(n=25)$, adalimumab $(n=25)$, golimumab $(n=24)$, and vedolizumab $(n=26)$ after their sequential regulatory approval.[31] Corticosteroid-free clinical remission rates at week-6, -14 and -54 were $40 \%, 28 \%, 32 \%$ for infliximab, $24 \%, 32 \%, 36 \%$ for adalimumab, $33 \%, 50 \%, 12 \%$ for golimumab, and $46 \%, 50 \%$, 26\% for vedolizumab, respectively, with no statistically significant differences between them.[31]

A retrospective multicenter study evaluated outcomes of UC patients unresponsive, intolerant, or with a secondary loss of response to adalimumab and golimumab, in whom therapy was switched to infliximab.[32] Seventy-six patients were included (50\% started adalimumab, 50\% started golimumab). The majority of patients had primary non-response to the first-line biologic as indication for switching to infliximab. Clinical response at 3, 6 and 12 months was seen in 65\%, 48\% and 36\% of patients, respectively. Clinical remission at 3, 6, and 12 months was reached in 36\%, 34\%, and 30\% of patients, respectively. Endoscopic evaluation was performed in 63 patients, and mucosal healing was achieved in 13/63 patients $(20 \%)$. Although subcutaneous anti-TNF drugs are frequently used as second-line agent, the results of this study suggest that the clinical outcomes of second-line therapy with intravenous infliximab may be superior than those seen with second-line therapy with golimumab or adalimumab.[32]

Overall, in retrospective studies, golimumab was efficacious for inducing short-term clinical response and remission in $65.7 \%$ (range $52-85.5 \%$ ) and 41\% (range 32-50\%) of patients, respectively. Mid- and longterm clinical outcomes were assessed in only two studies. In one study corticosteroid-free remission was 
$14 \%$ at week 54, and in another study sustained clinical benefit was 57.7\% after a median follow-up of 12 months.

\section{$\underline{\text { Real world phase } 4 \text { post-marketing studies }}$}

GO-COLITIS is a post-marketing study carried out in the United Kingdom, including 205 anti-TNF naïve patients with moderate-to-severe UC receiving induction and maintenance therapy with golimumab. At week 6, clinical response rate was 68.8\%, and clinical remission rate was 38.5\%.[33] During the induction period, patients experienced significant improvements in disease-specific quality of life, including bowel symptoms, emotional function, systemic symptoms, and social function.[34] Of those patients who achieved clinical response at week 6, 37.1\% maintained clinical remission at week 54, and $30 \%$ were on clinical remission at this time point. Similar to the induction period, significant improvements were seen in quality of life after 54 weeks of treatment.[35] All patients who continued treatment with golimumab between week 54 and 66 maintained response, whereas $13 \%$ of patients who discontinued golimumab treatment at week 54 presented early relapse (i.e. relapse within 12 weeks of stopping golimumab treatment).[36]

GORE-UC is another, observational, multicenter, post-marketing study from Italy studying the effectiveness of golimumab in the real life setting.[37] The study includes a retrospective part, terminated in December 2016, and an ongoing prospective part. Results from an interim analysis have recently been presented. One hundred fifty-four UC patients were included, more than half were anti-TNF experienced, and most had pancolitis (61\%) with severe endoscopic activity (57.8\%). After a median follow-up on golimumab maintenance therapy of 44 weeks (range 4-130), persistence rate was $48.7 \%$, with no significant differences when stratifying patients according to previous anti-TNF exposure. Persistence rates were higher when only looking at patients that completed week 8 and 14 of treatment (54\% and $62.5 \%$, respectively).[37]

In the BE-SMART real life cohort, 91 UC patients treated with golimumab were evaluated; most of them were anti-TNF naïve (87\%).[38] Primary endpoint was corticosteroid-free golimumab continuation at week 26 , which was seen in $41 \%$ of patients. Short-term mucosal healing at week 14 was achieved in $40 \%$ of patients, but was only assessed in $60 \%$ of participants. Mucosal healing at week 14 was predictive of corticosteroid-free golimumab continuation at week $26(\mathrm{p}=0.002)$ and week $52(\mathrm{p}<0.001)$, as well as the 
therapeutic intervention-free survival $(p=0.026)$ and discontinuation-free survival $(p=0.002)$ after a median follow-up of 36 weeks (IQR 12-106).[38]

Concomitant use of immunosuppressants, drug optimization, persistence, and colectomy rates

Most of the studies reported the concomitant use of immunosuppressants with golimumab;[14,15,17,18,20,22,24,26-28,30,38] with a cumulative rate of $28.5 \%$ (range $6.7 \%-56.4 \%$ ) (Table 1).

Data on dose optimization was reported in five studies.[14,27-29,38] Bressler et al reported that golimumab dose optimization occurred in only 3.6\% of patients.[29] Bosca-Watts et al reported dose optimization requirement in 9 out of 33 patients (27.3\%) during the 14 weeks of follow-up, 4 patients reduced the interval every 2 weeks, whereas 5 patients increased the dose from $50 \mathrm{mg}$ to 100 mg every 4 weeks.[14] In the study by O'Connell et al, 31 out of 72 patients (43\%) required dose optimization during follow-up, with a median optimization-free survival of 6.5 months. Forty-one percent of patients underwent a dose increase, whereas 59\% shortened the dose interval.[28] Taxonera et al reported that 50 out of 114 experienced secondary loss of response, which led to drug optimization 31 patients (62\%) and discontinuation in 19 patients (38\%). Median time to optimization was 5 months, and in $90.3 \%$ of cases golimumab dose was increased from $50 \mathrm{mg}$ to $100 \mathrm{mg}$ every 4 weeks.[27] Bossuyt et al reported that 8 out of 37 patients $(21.6 \%)$ that continued on treatment with golimumab at week 26 , needed drug optimization. [38]

Although several studies reported drug survival at various time points, only a few evaluated golimumab persistence at 1 year or beyond. Bressler et al reported that $63 \%$ of patients remained on therapy after 1 year, with a median time to discontinuation of 530 days.[29] In the study by Taxonera et al, a median time to golimumab discontinuation of 4.7 months (IQR 3-8) was seen, and drug persistence at week 52 and week 104 was $62.6 \%$ and 38\%, respectively.[27] Berends et al, reported that 6 out 19 patients (31.6\%) initially enrolled, continued golimumab treatment at 1 year.[21]

Six studies reported wide ranging colectomy rates at various time points. Detrez et al reported that 5 out of 21 patients (23.8\%) needed colectomy within 1 year after the first golimumab injection,[15] whereas in the study by Tursi et al colectomy occurred in only 1 patient our of $91(1.1 \%)$ during the 6 months period of the study.[17] Bessuyt et al reported a colectomy rate of 3.2\% (3 out of 91 patients) within the first year of treatment.[38] In the study by Bossa et al, 10 out of 190 patients (5.2\%) required colectomy 
during the first year of treatment, importantly 7 of them where initially anti-TNF experienced.[18] Orlandini et al reported a colectomy rate of $22 \%$ (13/59 patients) after 2 years of follow up, which was numerically higher in anti-TNF experienced patients (31\% versus 11\%).[20] Taxonera et al found that $10.6 \%$ patients $(15 / 142)$ needed colectomy after a median time of 4 months, surgery rate was significantly lower in anti-TNF naïve patients compared to those previously exposed to 1 or more than 1 anti-TNF agents $(1.7 \%, 12.1 \%$, and $19.2 \%$, respectively).[27]

\section{Conclusion}

The efficacy of golimumab as induction and maintenance therapy in moderate-to-severe UC has been demonstrated in the phase 3 PURSUIT randomized controlled trials.[12,13] In the induction study, the primary outcome of week- 6 clinical response was achieved in $51 \%$ of patients in the golimumab arm (200/100 mg induction dose) compared to $30 \%$ of patients in the placebo arm ( $\mathrm{p} \leq 0.0001)$.[13] Key secondary outcomes, week- 6 clinical remission and mucosal healing, were also significantly higher in the golimumab arms than in the placebo arms $[17.8 \%$ versus $6.4 \%(\mathrm{p}<0.0001)$, and $42.3 \%$ versus $28.7 \%$ $(p=0.0014)$, respectively].[13] In the maintenance study used a complex design, which consisted of monthly clinical assessments in order to ensure clinical response and the full Mayo Clinic score (including the endoscopic subscore) at week 30 and week 54. Week-54 clinical response was maintained in $47.0 \%$ of patients in the golimumab $50 \mathrm{mg}$ arm, $49.7 \%$ of patients in the golimumab $100 \mathrm{mg}$ arm, and $31.2 \%$ of patients in the placebo arm ( $\mathrm{p}=0.010$ and $\mathrm{p}<0.001$, respectively).[12] Clinical remission and mucosal healing at both week-30 and week-54 were again significantly higher in the golimumab arms $50 \mathrm{mg}$ and $100 \mathrm{mg}$ than in the placebo arms [23.2\% versus $27.8 \%$ versus $15.6 \%$, and $41.7 \% \%$ versus $42.4 \%$ versus 26.6\%, respectively].[12] Hence, induction treatment with golimumab consists of two subcutaneous injections of $200 \mathrm{mg}$ and $100 \mathrm{mg}$ at week 0 and week 2, respectively. As maintenance treatment, the European Medicines Agency (EMA) advices to use $50 \mathrm{mg}$ or $100 \mathrm{mg}$ of golimumab every 4 weeks in patients with a body weight of less than $80 \mathrm{~kg}$ or more than $80 \mathrm{~kg}$, respectively. If national guidelines allow, golimumab dosing could be intensified in cases of persistent disease activity or loss of response.[39]

Studies that evaluate effectiveness in the real world setting are relevant to confirm the clinical benefit of a given drug and endorse its use, since patients enrolled in randomized controlled trials are highly selected, and not always representative of those seen in routine clinical practice. Moreover, real world data on the 
effectiveness of infliximab and adalimumab have shown better results in clinical practice compared with randomized controlled trials results.[40,41] The pivotal trials with golimumab only included anti-TNF naïve patients, however golimumab was the last anti-TNF to be approved in UC, and a considerable number of patients seen in clinical practice were previously exposed to infliximab and/or adalimumab. Overall, the clinical outcomes of observational studies are numerically similar than those seen in the PURSUIT trials, but taking into account that they included a mixed anti-TNF naïve and experienced population. Most of the studies evaluated short-term clinical outcomes (between week 6 and 14), in which clinical response ranged between $35 \%$ and $85.5 \%$, and clinical remission between $14 \%$ and $51.5 \%$. Pooled short-term clinical response and remission rates were $59.3 \%$ and $35.9 \%$, respectively (Figure 1). Some studies also evaluated mid-term and long-term clinical outcomes at 6 or 12 months, in which clinical remission ranged widely between $12 \%$ and $84.2 \%$. Pooled mid- and long-term clinical response and remission rates were $60.3 \%$ and $39.2 \%$, respectively (Figure 1). Given the wide range of results, these data should be interpreted with caution, and this heterogeneity could be explained by several factors. Firstly, although most of the studies reported mid- and long-term outcomes using an intention-to-treat analysis, some studies used an initial-responder analysis (table 1). Secondly, considering that all studies were carried out in the real life setting, selection of patients in referral and non-referral centers could also explain in part heterogeneity of results. Finally, definition on clinical outcomes, time point at which they were measured, as well as follow-up time, varied considerably between studies, limiting the ability to make direct comparisons. Notably, many studies from Italy were identified and included, which might have led to duplication and bias. However, most of the studies were prospective and from different regions of the country.

Some studies have evaluated objective outcomes like CRP and fecal calprotectin levels, in which golimumab treatment induced a significant decrease. However, an important limitation of most of the evaluated studies is the lack of endoscopic outcomes, since mucosal healing was only assessed in four studies. STRIDE consensus endorses the use of clinical (patient reported outcomes) and endoscopic outcomes as therapeutic goals in clinical practice.[42] In the few studies that evaluated endoscopy as outcomes measures, mucosal healing ranged widely between $19.3 \%$ and $53 \%$.

Notably, safety was also evaluated in some of the studies, with no new safety signals detected in routine clinical practice. Nevertheless, these studies are underpowered and follow-up is usually too short to detect relatively infrequent adverse events. Hence, large post-marketing registries to evaluate the 
incidence of rare and serious adverse events, such as the currently ongoing I-CARE trial (NCT02377258), are warranted.

In conclusion, the results seen in observational real world studies confirm golimumab as an effective therapy for UC patients in daily practice. As seen with other biologics, anti-TNF naïve patient seem to respond better to golimumab treatment, but golimumab also retains some effectiveness in anti-TNF experienced population. Golimumab seems a reasonable choice as first line anti-TNF in moderate to severe UC (outside the context of acute severe UC) but also in biologic experienced patients with other associated indications for anti-TNF therapy, such as extraintestinal manifestations.

\section{Tables and Figures:}

Figure 1: Pooled response rates. Panel A) pooled short-term (6 to 14 weeks) clinical response and remission rates. Panel B) pooled mid- and long-term (24 to 54 weeks) clinical response and remission rates.

Table 1: Outcomes in observational real world studies with golimumab in ulcerative colitis.

\section{Conflict of interests:}

PO has received financial support for research from Abbvie, Ferring and Takeda, and lecture fees from Takeda. SD has served as a speaker, a consultant, and an advisory board member for Abbvie, Allergan, Biogen, Boehringer Ingelheim, Celgene, Celltrion, Ferring, Hospira, Johnson \& Johnson, Merck, MSD, Takeda, Mundipharma, Pfizer, Sandoz, Tigenix, UCB Pharma, and Vifor. LP has received travel fees from Ferring and Takeda. LPB has received consulting fees from Abbvie, Amgen, Biogaran, Biogen, BoerhingerIngelheim, Bristol-Myers Squibb, Celgene, Celltrion, Ferring, Forward Pharma, Genentech, H.A.C. Pharma, Hospira, Index Pharmaceuticals, Janssen, Lycera, Merck, Lilly, Mitsubishi, Norgine, Pfizer, Pharmacosmos, Pilège, Samsung Bioepis, Sandoz, Takeda, Therakos, Tillots, UCB Pharma, and Vifor and lecture fees from Abbvie, Ferring, H.A.C. Pharma, Janssen, Merck, Mitsubishi, Norgine, Takeda, Therakos, Tillots, and Vifor. SB declares no conflict of interest.

References:

[1] Ungaro R, Mehandru S, Allen PB, Peyrin-Biroulet L, Colombel J-F. Ulcerative colitis. Lancet 2017;389:1756-70. doi:10.1016/S0140-6736(16)32126-2. 
bowel diseases. Gastroenterology 2011;140:1785-94. doi:10.1053/j.gastro.2011.01.055.

[3] Van Assche G, Peyrin-Biroulet L, Sturm A, Gisbert JP, Gaya DR, Bokemeyer B, et al. Burden of disease and patient-reported outcomes in patients with moderate to severe ulcerative colitis in the last 12 months - Multicenter European cohort study. Dig Liver Dis 2016;48:592-600. doi:10.1016/j.dld.2016.01.011.

[4] Ng SC, Shi HY, Hamidi N, Underwood FE, Tang W, Benchimol EI, et al. Worldwide incidence and prevalence of inflammatory bowel disease in the 21st century: a systematic review of populationbased studies. Lancet 2017;390:2769-78. doi:10.1016/S0140-6736(17)32448-0.

[5] Colombel JF, Rutgeerts P, Reinisch W, Esser D, Wang Y, Lang Y, et al. Early mucosal healing with infliximab is associated with improved long-term clinical outcomes in ulcerative colitis. Gastroenterology 2011;141:1194-201. doi:10.1053/j.gastro.2011.06.054.

[6] Peyrin-Biroulet L, Bressenot A, Kampman W. Histologic remission: the ultimate therapeutic goal in ulcerative colitis? Clin Gastroenterol Hepatol 2014;12:929-34.e2. doi:10.1016/j.cgh.2013.07.022.

[7] Olivera P, Spinelli A, Gower-Rousseau C, Danese S, Peyrin-Biroulet L. Surgical rates in the era of biological therapy: Up, down or unchanged? Curr Opin Gastroenterol 2017;33:246-53. doi:10.1097/MOG.0000000000000361.

[8] Smolen JS, Kay J, Doyle MK, Landewé R, Matteson EL, Wollenhaupt J, et al. Golimumab in patients with active rheumatoid arthritis after treatment with tumour necrosis factor alpha inhibitors (GOAFTER study): a multicentre, randomised, double-blind, placebo-controlled, phase III trial. Lancet (London, England) 2009;374:210-21. doi:10.1016/S0140-6736(09)60506-7.

[9] Kavanaugh A, van der Heijde D, McInnes IB, Mease P, Krueger GG, Gladman DD, et al. Golimumab in psoriatic arthritis: one-year clinical efficacy, radiographic, and safety results from a phase III, randomized, placebo-controlled trial. Arthritis Rheum 2012;64:2504-17. doi:10.1002/art.34436.

[10] Inman RD, Davis JC, Heijde D van der, Diekman L, Sieper J, Kim S Il, et al. Efficacy and safety of golimumab in patients with ankylosing spondylitis: results of a randomized, double-blind, placebo-controlled, phase III trial. Arthritis Rheum 2008;58:3402-12. doi:10.1002/art.23969.

[11] Brunner HI, Ruperto N, Tzaribachev N, Horneff G, Chasnyk VG, Panaviene V, et al. Subcutaneous golimumab for children with active polyarticular-course juvenile idiopathic arthritis: results of a multicentre, double-blind, randomised-withdrawal trial. Ann Rheum Dis 2018;77:21-9. 
doi:10.1136/annrheumdis-2016-210456.

[12] Sandborn WJ, Feagan BG, Marano C, Zhang H, Strauss R, Johanns J, et al. Subcutaneous golimumab maintains clinical response in patients with moderate-to-severe ulcerative colitis.

Gastroenterology 2014;146:96-109.e1. doi:10.1053/j.gastro.2013.06.010.

[13] Sandborn WJ, Feagan BG, Marano C, Zhang H, Strauss R, Johanns J, et al. Subcutaneous Golimumab Induces Clinical Response and Remission in Patients With Moderate-to-Severe Ulcerative Colitis. Gastroenterology 2014;146:85-95. doi:10.1053/j.gastro.2013.05.048.

[14] Bosca-Watts MM, Cortes X, Iborra M, Huguet JM, Sempere L, Garcia G, et al. Short-term effectiveness of golimumab for ulcerative colitis: Observational multicenter study. World J Gastroenterol 2016;22:10432-9. doi:10.3748/wjg.v22.i47.10432.

[15] Detrez I, Dreesen E, Van Stappen T, de Vries A, Brouwers E, Van Assche G, et al. Variability in golimumab exposure: A “real-life” observational study in active ulcerative colitis. J Crohn's Colitis 2016;10:575-81. doi:10.1093/ecco-jcc/jjv241.

[16] Renna S, Orlando E, Macaluso FS, Maida M, Affronti M, Giunta M, et al. Letter: a prospective real life comparison of the efficacy of adalimumab vs. golimumab in moderate to severe ulcerative colitis. Aliment Pharmacol Ther 2016;44:310-1. doi:10.1111/apt.13692.

[17] Tursi A, Allegretta L, Buccianti N, Valle N Della, Elisei W, Forti G, et al. Effectiveness and safety of golimumab in treating outpatient ulcerative colitis: A real-life prospective, multicentre, observational study in primary inflammatory bowel diseases centers. J Gastrointest Liver Dis 2017;26:239-44. doi:10.15403/jgld.2014.1121.263.trs.

[18] Bossa F, Valvano MR, Costantino G, Vinci E, Rispo A, Mendolaro M, et al. P621 Efficacy and safety of golimumab in ulcerative colitis. Preliminary data from a multicenter Italian study. J Crohn's Colitis 2017;11:S397-8. doi:10.1093/ecco-jcc/jjx002.745.

[19] Orlando A, Macaluso FS, Fries W, Privitera AC, Cappello M, Siringo S, et al. P412 The Sicilian network of biological therapy in inflammatory bowel disease: preliminary data on efficacy. J Crohn's Colitis 2017;11:S286-7. doi:10.1093/ecco-jcc/jjx002.537.

[20] Orlandini, B; Capoferro, E; Bagnoli, S; Dragoni, G; Geccherle, A; Rogai F. Clinical efficacy and safety of golimumab in biologic naïve and experienced patients with active ulcerative colitis nonresponder or intolerant to conventional therapies. United Eur Gastroenterol J 2017;5:A532-3. doi:10.1177/2050640617725676. 
[21] Berends S, Strik A, Jansen J, de Boer N, Brandse J, D’Haens G, et al. P690 Clinical and endoscopic outcomes of one year golimumab treatment in patients with active ulcerative colitis: A real-life observational study. J Crohn's Colitis 2018;12:S459-60. doi:10.1093/ecco-jcc/jjx180.817.

[22] Armuzzi A, Marchi S, Gasbarrini A, Saibeni S, Geccherle A, Principi M, et al. P762 GO-CARE: A prospective multi-centre observational study of golimumab effectiveness and quality of life in a real-life UC patient population in Italy. J Crohn's Colitis 2018;12:S496-7. doi:10.1093/eccojcc/jjx180.889.

[23] Teich N, Grümmer H, Jörgensen E, Liceni T, Holtkamp-Endemann F, Cornillie F, et al. P558 Golimumab improves patient-reported work productivity and activity impairment in patients with ulcerative colitis: Interim results from a non-interventional trial in Germany. J Crohn's Colitis 2018;12:S388-S388. doi:10.1093/ecco-jcc/jjx180.685.

[24] Eriksson C, Bergemalm D, Vigren L, Nilsson L, Visuri I, Hjortswang H, et al. P595 Clinical effectiveness of golimumab: Interim analysis of the observational study of patients with ulcerative colitis on golimumab in the Swedish National Quality Registry for IBD-GO-SWIBREG. J Crohn's Colitis 2018;12:S409-10. doi:10.1093/ecco-jcc/jjx180.722.

[25] Girardin G, Savarino EV, Zingone F, Marinelli C, Inferrera M, Lorenzon G, et al. P.07.3 EFFECTIVENESS OF GOLIMUMAB IN REAL LIFE - A SINGLE CENTER PROSPECTIVE STUDY. Dig Liver Dis 2018;50:e193-4. doi:10.1016/S1590-8658(18)30553-X.

[26] Castro-Laria L, Argüelles-Arias F, García-Sánchez V, Benítez JM, Fernández-Pérez R, TraperoFernández AM, et al. Initial experience with golimumab in clinical practice for ulcerative colitis. Rev Esp Enferm Dig 2016;108:129-32. doi:10.17235/reed.2016.4068/2015.

[27] Taxonera C, Rodríguez C, Bertoletti F, Menchén L, Arribas J, Sierra M, et al. Clinical Outcomes of Golimumab as First, Second or Third Anti-TNF Agent in Patients with Moderate-to-Severe Ulcerative Colitis. Inflamm Bowel Dis 2017;23:1394-402. doi:10.1097/MIB.0000000000001144.

[28] O’Connell J, Rowan C, Stack R, Harkin G, Parihar V, Chan G, et al. Golimumab effectiveness and safety in clinical practice for moderately active ulcerative colitis. Eur J Gastroenterol Hepatol 2018. doi:10.1097/MEG.0000000000001177.

[29] Bressler, B; Williamson, M; Camacho, F; Sttin, B; Steinhart AH. P583. Real-world use and effectiveness of golimumab for ulcerative colitis in Canada. J Crohn's Colitis 2016;10:S396.2-S396. doi:10.1093/ecco-jcc/jjw019.702. 
[30] Biscaglia G, Savarino E, Variola A, Furfaro F, Ferracane C, Rizzati G, et al. P613 Predictors of treatment persistence in ulcerative colitis patients treated with golimumab: A multicentre cohort study. J Crohn's Colitis 2018;12:S419-S419. doi:10.1093/ecco-jcc/jjx180.740.

[31] Cassinotti A, Mezzina N, Massari A, Grillo S, Ardizzone S. P702 Head-to-head comparison of biological drugs in the treatment of ulcerative colitis: Suggestions from a real-life, inception cohort, single-centre study on consecutive post-marketing treatments. J Crohn's Colitis 2018;12:S466-S466. doi:10.1093/ecco-jcc/jjx180.829.

[32] Viola A, Pugliese D, Renna S, Furfaro F, Caprioli F, D’Incà R, et al. P.07.2 OUTCOME IN ULCERATIVE COLITIS AFTER SWITCH FROM SUBCUTANEOUS ANTI-TNF TO INTRAVENOUS ANTI-TNF: A MULTICENTRE STUDY. Dig Liver Dis 2018;50:e193. doi:10.1016/S1590-8658(18)30552-8.

[33] Probert, C; Gaya, D; Hamlin, P; Irving, P; Sebastian, S; Gillespie, G; Tate, H; Wheeler H. DOP049. Efficacy and safety of golimumab induction for moderate-to-severe ulcerative colitis in the United Kingdom: results from the GO-COLITIS study. J Crohn's Colitis 2016;10:S57-8. doi:10.1093/eccojcc/jjw019.078.

[34] Irving, P; Probert, C; Gaya, D; Hamlin, H; Sebastian, S; Gillespie, G; Tate, H; Wheeler C. P310. Patient-reported quality of life during golimumab induction for moderate-to-severe ulcerative colitis in the United Kingdom: results from the GO-COLITIS study. J Crohn's Colitis 2016;10:S2501. doi:10.1093/ecco-jcc/jjw019.429.

[35] Gaya DR, Irving P, Sebastian S, Hamlin PJ, Wheeler C, Rose A, et al. P1057. GO-COLITIS: Efficacy and Quality of Life During Golimumab Maintenance in UK Patients with Moderate to Severe Ulcerative Colitis. United Eur Gastroenterol J 2017;5.

[36] Hamlin, P; Sebastien, S; Irving, P; Gaya, D, Wheeler, C; Rose, A; Gillespie, G; Probert C. OP100. Early Relapse of Ulcerative Colitis after Discontinuation of Treatment in Patients Responding to Golimumab. United Eur Gastroenterol J 2017;5.

[37] Pugliese D, Rogai F, Variola A, Viola A, Privitera A, Allocca M, et al. P.02.10 REAL-LIFE STUDY (GORE-UC) EVALUATING THE EFFECTIVENESS OF GOLIMUMAB FOR THE TREATMENT OF ULCERATIVE COLITIS: AN INTERIM ANALYSIS FROM ITALIAN GROUP FOR THE STUDY OF INFLAMMATORY BOWEL DISEASE (IG-IBD). vol. 50. 2018. doi:10.1016/S1590-8658(18)30423-7.

[38] Bossuyt P, Baert F, D’Heygere F, Nakad A, Reenaers C, Fontaine F, et al. Early Mucosal Healing Predicts Favorable Outcomes in Patients With Moderate to Severe Ulcerative Colitis Treated With 
Golimumab: Data From the Real-life BE-SMART Cohort. Inflamm Bowel Dis 2018:izy219-izy219. doi:10.1093/ibd/izy219.

[39] Löwenberg M, de Boer NK, Hoentjen F. Golimumab for the treatment of ulcerative colitis. Clin Exp Gastroenterol 2014;7:53-9. doi:10.2147/CEG.S48741.

[40] Sandborn WJ, Sakuraba A, Wang A, Macaulay D, Reichmann W, Wang S, et al. Comparison of realworld outcomes of adalimumab and infliximab for patients with ulcerative colitis in the United States. Curr Med Res Opin 2016;32:1233-41. doi:10.1185/03007995.2016.1168290.

[41] García-Bosch O, Gisbert JP, Cañas-Ventura A, Merino O, Cabriada JL, García-Sánchez V, et al. Observational study on the efficacy of adalimumab for the treatment of ulcerative colitis and predictors of outcome. J Crohns Colitis 2013;7:717-22. doi:10.1016/j.crohns.2012.10.004.

[42] Peyrin-Biroulet L, Sandborn W, Sands BE, Reinisch W, Bemelman W, Bryant R V, et al. Selecting Therapeutic Targets in Inflammatory Bowel Disease (STRIDE): Determining Therapeutic Goals for Treat-to-Target. Am J Gastroenterol 2015;110:1324-38. doi:10.1038/ajg.2015.233. 


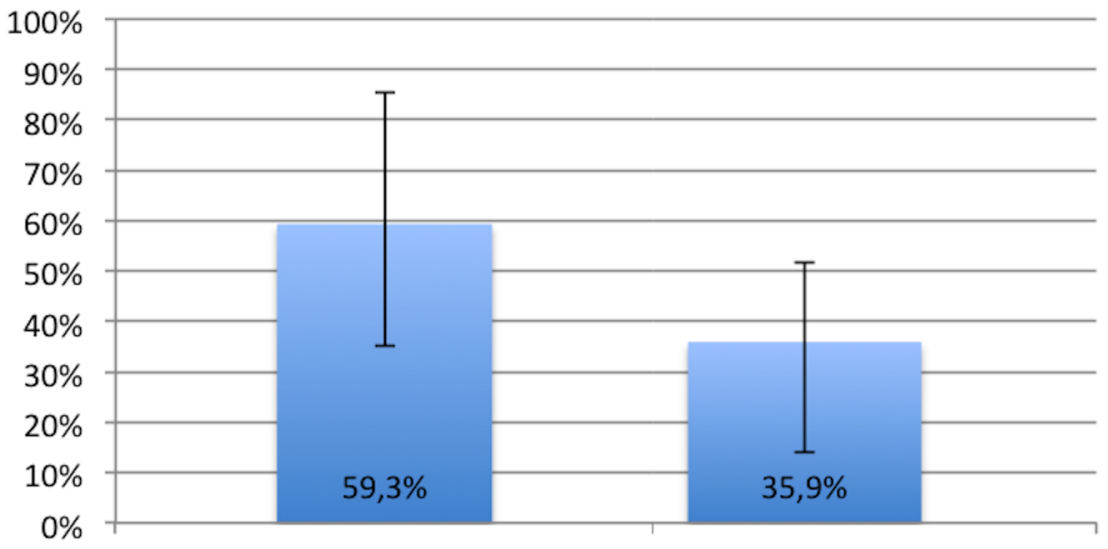

Clinical Response

Clinical Remission

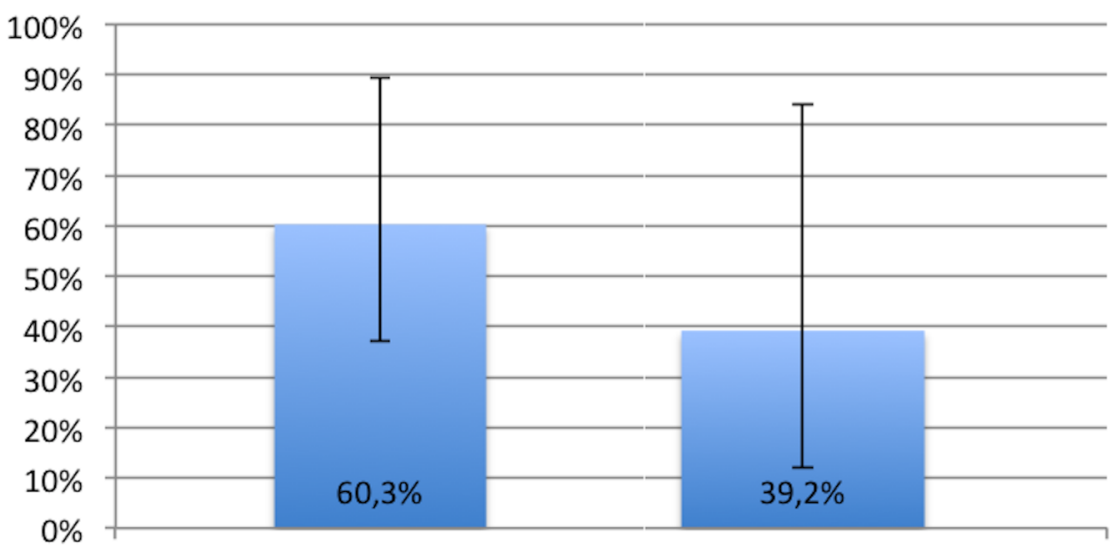


Table 1: Outcomes in observational real world studies with golimumab in ulcerative colitis

\begin{tabular}{|c|c|c|c|c|c|c|c|c|}
\hline Study & Study design & Country & Number of patients & Studied population & Follow up & $\begin{array}{l}\text { Short-term clinical } \\
\text { outcomes }\end{array}$ & $\begin{array}{l}\text { Mid- and Long-term } \\
\text { clinical outcomes }\end{array}$ & $\begin{array}{l}\text { Objective } \\
\text { measurements }\end{array}$ \\
\hline $\begin{array}{l}\text { Bosca- } \\
\text { Watts et } \\
\text { al. }^{13}\end{array}$ & Multicenter prospective cohort & Spain & 33 & $\begin{array}{l}27.3 \% \text { anti-TNF naïve } \\
(9 / 33) \\
72.7 \% \text { anti-TNF } \\
\text { experienced ( } 24 / 33 ; \\
16 / 24>1 \text { anti-TNF } \\
\text { agent) } \\
\text { Concomitant IS: } 36.6 \%\end{array}$ & 14 weeks & $\begin{array}{l}\text { W14 clinical response: } \\
69.7 \% \text { (anti-TNF naïve: } \\
66.7 \% \text { ) } \\
\text { W14 clinical remission: } \\
51.7 \%\end{array}$ & - & $\begin{array}{l}\text { Mean FCP: } \\
\text { Baseline: } 300 \mathrm{ug} / \mathrm{g} \\
\text { W14: } 170.5 \mathrm{ug} / \mathrm{g} \\
\text { Mean CRP: } \\
\text { Baseline: } 11.9 \\
\text { mg/dL } \\
\text { W14: } 3.4 \mathrm{mg} / \mathrm{dL}\end{array}$ \\
\hline $\begin{array}{l}\text { Detrez et } \\
\text { al. }{ }^{14}\end{array}$ & $\begin{array}{l}\text { Single center prospective } \\
\text { cohort }\end{array}$ & Belgium & 21 & $\begin{array}{l}52 \% \text { anti-TNF naïve } \\
(11 / 21) \\
48 \% \text { anti-TNF } \\
\text { experienced (10/21) } \\
\text { Concomitant IS: } 21 \%\end{array}$ & 14 weeks & $\begin{array}{l}\text { W14 clinical response: } \\
\text { 48\% } \\
\text { W14 clinical remission: } \\
14 \%\end{array}$ & - & $\begin{array}{l}\text { W14 mucosal healing: } \\
28 \%\end{array}$ \\
\hline $\begin{array}{l}\text { Renna et } \\
\text { al. }^{15}\end{array}$ & $\begin{array}{l}\text { Single center prospective } \\
\text { cohort }\end{array}$ & Italy & $\begin{array}{l}40 \text { (19 treated with } \\
\text { golimumab) }\end{array}$ & $\begin{array}{l}26.3 \% \text { anti-TNF naïve } \\
(5 / 19) \\
73.7 \% \text { anti-TNF } \\
\text { experienced (14/19; } \\
5 / 14>1 \text { anti-TNF } \\
\text { agent) }\end{array}$ & 8 weeks & $\begin{array}{l}\text { W8 clinical remission: } \\
31.5 \text { (anti-TNF naïve } \\
40 \% \text {, anti-TNF } \\
\text { experienced: } 28 \% \text { ) }\end{array}$ & - & - \\
\hline $\begin{array}{l}\text { Tursi et } \\
\text { al. }{ }^{16}\end{array}$ & Multicenter prospective cohort & Italy & 93 & $\begin{array}{l}88.8 \% \text { anti-TNF naïve } \\
(84 / 93) \\
11.2 \% \text { anti-TNF } \\
\text { experienced ( } 9 / 93 \text { ) } \\
\text { Concomitant IS: } 16.1 \%\end{array}$ & 26 weeks & $\begin{array}{l}\text { W12 clinical response: } \\
77.4 \% \\
\text { W12 clinical remission: } \\
44.1 \%\end{array}$ & $\begin{array}{l}\text { W26 clinical response: } \\
64.5 \% \\
\text { W26 clinical remission: } \\
36.5 \% \text { ( } 47 \% \text { on } \\
\text { steroids) }\end{array}$ & $\begin{array}{l}\text { W26 mucosal healing: } \\
19.3 \%\end{array}$ \\
\hline $\begin{array}{l}\text { O'Connell } \\
\text { et al. }{ }^{17}\end{array}$ & $\begin{array}{l}\text { Multicenter retrospective } \\
\text { cohort }\end{array}$ & Ireland & 72 & $\begin{array}{l}\text { 64\% anti-TNF naïve } \\
(46 / 72) \\
36 \% \text { anti-TNF } \\
\text { experienced }(26 / 72 ; \\
8 / 26>1 \text { anti-TNF } \\
\text { agent) } \\
\text { Concomitant IS: } 44 \%\end{array}$ & $\begin{array}{l}\text { Median } 8.7 \text { months } \\
\text { (range 0.4-39.2) }\end{array}$ & $\begin{array}{l}\text { W12 clinical response: } \\
55 \%\end{array}$ & $\begin{array}{l}\text { W24 CS-free clinical } \\
\text { remission: } 39 \% \text { (anti- } \\
\text { TNF naïve: } 42 \% ; 1 \\
\text { previous anti-TNF: } \\
40 \% ; 2 \text { previous anti- } \\
\text { TNF: } 17 \% \text { ) }\end{array}$ & $\begin{array}{l}\text { Median CRP: } \\
\text { Baseline: } 3.5 \mathrm{mg} / \mathrm{dL} \\
\text { W12: } 2.2 \mathrm{mg} / \mathrm{dL}\end{array}$ \\
\hline $\begin{array}{l}\text { Bossa et } \\
\text { al. }{ }^{18}\end{array}$ & Multicenter prospective cohort & Italy & 190 & $\begin{array}{l}\text { 65.7\% anti-TNF naïve } \\
(125 / 190) \\
34.3 \% \text { anti-TNF } \\
\text { experienced (65/190; } \\
19 / 65>1 \text { anti-TNF } \\
\text { agent) } \\
\text { Concomitant IS: } 11.6 \%\end{array}$ & 12 weeks & $\begin{array}{l}\text { W12 clinical response: } \\
60 \% \\
\text { W12 clinical remission: } \\
39 \%\end{array}$ & - & $\begin{array}{l}\text { W12 mucosal healing: } \\
53 \%\end{array}$ \\
\hline $\begin{array}{l}\text { Orlando et } \\
\text { al. }^{19}\end{array}$ & Multicenter prospective cohort & Italy & $\begin{array}{l}335 \text { UC patients } \\
\text { treated with biologics }\end{array}$ & $\begin{array}{l}55.4 \% \text { biologic-naïve } \\
44.6 \% \text { biologic- } \\
\text { experienced }\end{array}$ & 52 weeks & $\begin{array}{l}\text { W12 clinical response: } \\
56.6 \%\end{array}$ & $\begin{array}{l}\text { W52 clinical remission: } \\
38.2 \%\end{array}$ & - \\
\hline $\begin{array}{l}\text { Orlandini } \\
\text { et al. }{ }^{20}\end{array}$ & Multicenter prospective cohort & Italy & 59 & $\begin{array}{l}45.7 \% \text { biologic-naïve } \\
(27 / 59) \\
54.3 \% \text { biologic- } \\
\text { experienced }(32 / 59)\end{array}$ & 12 weeks & $\begin{array}{l}\text { W12 clinical response: } \\
48 \% \text { (anti-TNF naïve } \\
58 \% \text {, anti-TNF } \\
\text { experienced: } 40 \% \text { ) }\end{array}$ & - & - \\
\hline
\end{tabular}




\begin{tabular}{|c|c|c|c|c|c|c|c|c|}
\hline & & & & Concomitant IS: $6.7 \%$ & & & & \\
\hline $\begin{array}{l}\text { Berends et } \\
\text { al. }{ }^{21}\end{array}$ & Multicenter prospective cohort & $\begin{array}{l}\text { The } \\
\text { Netherlands }\end{array}$ & 20 & NA & 52 weeks & - & $\begin{array}{l}\text { W52 clinical response: } \\
50 \% \\
\text { W52 clinical remission: } \\
30 \% \\
\text { (among initial } \\
\text { responders) }\end{array}$ & $\begin{array}{l}\text { W8-10 endoscopic } \\
\text { response: } 63 \%\end{array}$ \\
\hline $\begin{array}{l}\text { Armuzzi et } \\
\text { al. }{ }^{22}\end{array}$ & Multicenter prospective cohort & Italy & $\begin{array}{l}83 \text { completed } 8 \text { weeks } \\
38 \text { completed } 32 \\
\text { weeks }\end{array}$ & $\begin{array}{l}72.3 \% \text { anti-TNF naïve } \\
27.7 \% \text { anti-TNF } \\
\text { experienced } \\
\text { Concomitant IS: } 15.7 \%\end{array}$ & 32 weeks & - & $\begin{array}{l}\text { W32 clinical response: } \\
89.5 \% \\
\text { W32 clinical remission: } \\
84 \% \\
\text { (among initial } \\
\text { responders) }\end{array}$ & $\begin{array}{l}\text { Median CRP: } \\
\text { Baseline: } 3.6 \mathrm{mg} / \mathrm{dL} \\
\text { W8: } 3 \mathrm{mg} / \mathrm{dL} \\
\text { W32: } 2.1 \mathrm{mg} / \mathrm{dL}\end{array}$ \\
\hline $\begin{array}{l}\text { Eriksson et } \\
\text { al. }{ }^{24}\end{array}$ & Multicenter prospective cohort & Sweden & 50 & $\begin{array}{l}30 \% \text { anti-TNF naïve } \\
(15 / 50) \\
70 \% \text { anti-TNF } \\
\text { experienced (35/50) } \\
\text { Concomitant IS: } 48 \%\end{array}$ & 12 weeks & $\begin{array}{l}\text { W12 clinical response: } \\
35 \% \\
\text { W12 clinical remission: } \\
22 \%\end{array}$ & - & $\begin{array}{l}\text { Median FCP: } \\
\text { Baseline: } 710 \text { ug/g } \\
\text { W12: } 390 \text { ug/g }\end{array}$ \\
\hline $\begin{array}{l}\text { Girardin et } \\
\text { al. }{ }^{25}\end{array}$ & $\begin{array}{l}\text { Single center prospective } \\
\text { cohort }\end{array}$ & Italy & 34 & NA & 26 weeks & $\begin{array}{l}\text { W6 clinical response: } \\
58 \%\end{array}$ & $\begin{array}{l}\text { W26 clinical remission: } \\
44 \% \text { (of initial } \\
\text { responders) }\end{array}$ & $\begin{array}{l}\text { Median FCP: } \\
\text { Baseline } \\
\text { responders: } 900 \\
\text { ug/g } \\
\text { Baseline non- } \\
\text { responders: } 1912 \\
\text { ug/g } \\
\text { W6 responders: } \\
271.5 \mathrm{ug} / \mathrm{g} \\
\text { W6 non- } \\
\text { responders: } 1076 \\
\text { ug/g }\end{array}$ \\
\hline $\begin{array}{l}\text { Castro- } \\
\text { Laria et } \\
\text { al. }{ }^{26}\end{array}$ & $\begin{array}{l}\text { Multicenter retrospective } \\
\text { cohort }\end{array}$ & Spain & 23 & $\begin{array}{l}30.4 \% \text { anti-TNF naïve } \\
(7 / 23) \\
69.6 \% \text { anti-TNF } \\
\text { experienced }(16 / 23 ; \\
12 / 16>1 \text { anti-TNF } \\
\text { agent) } \\
\text { Concomitant IS: } 56.4 \%\end{array}$ & Mean 14.3 weeks & $\begin{array}{l}\text { Clinical response: } \\
\text { 85.5\% (anti-TNF } \\
\text { naïve), 75\% (anti-TNF } \\
\text { experienced) }\end{array}$ & - & - \\
\hline $\begin{array}{l}\text { Taxonera } \\
\text { et al. }{ }^{27}\end{array}$ & $\begin{array}{l}\text { Multicenter retrospective } \\
\text { cohort }\end{array}$ & Spain & 142 & $\begin{array}{l}40.2 \% \text { anti-TNF naïve } \\
(57 / 142) \\
59.8 \% \text { anti-TNF } \\
\text { experienced (85/142; } \\
52 / 85>1 \text { anti-TNF } \\
\text { agent) } \\
\text { Concomitant IS: } 46.5 \%\end{array}$ & $\begin{array}{l}\text { Median } 12 \text { months } \\
\text { (IQR 6-18) }\end{array}$ & $\begin{array}{l}\text { W8 clinical response: } \\
65 \% \text { (anti-TNF naïve: } \\
\text { 75.4\%; } 1 \text { previous anti- } \\
\text { TNF: } 69.7 \% \text {; } 2 \text { previous } \\
\text { anti-TNF: } 50 \% \text { ) } \\
\text { W8 clinical remission: } \\
\text { 32\% (anti-TNF naïve: } \\
\text { 43.9\%; } 1 \text { previous anti- } \\
\text { TNF: } 33.3 \% \text {; } 2 \text { previous } \\
\text { anti-TNF: } 17.3 \% \text { ) }\end{array}$ & $\begin{array}{l}\text { Sustained clinical } \\
\text { benefit: } 57.7 \% \\
\text { (among initial } \\
\text { responders) }\end{array}$ & - \\
\hline $\begin{array}{l}\text { Biscaglia et } \\
\text { al. }{ }^{29}\end{array}$ & $\begin{array}{l}\text { Multicenter retrospective } \\
\text { cohort }\end{array}$ & Italy & 172 & $\begin{array}{l}54.7 \% \text { biologic-naïve } \\
(94 / 172) \\
45.3 \% \text { biologic- } \\
\text { experienced ( } 78 / 172) \\
\\
\text { Concomitant IS: } 14.5 \%\end{array}$ & NA & $\begin{array}{l}\text { W12 clinical response: } \\
52 \%\end{array}$ & - & - \\
\hline
\end{tabular}




\begin{tabular}{|c|c|c|c|c|c|c|c|c|}
\hline $\begin{array}{l}\text { Cassinotti } \\
\text { et al. }{ }^{30}\end{array}$ & $\begin{array}{l}\text { Single center retrospective } \\
\text { inception cohort }\end{array}$ & Italy & $\begin{array}{l}100 \text { ( } 25 \text { treated with } \\
\text { golimumab) }\end{array}$ & $\mathrm{NA}$ & 54 weeks & $\begin{array}{l}\text { W6 CS-free clinical } \\
\text { remission: } 33 \% \\
\text { W14 CS-free clinical } \\
\text { remission: } 50 \%\end{array}$ & $\begin{array}{l}\text { W54 CS-free clinical } \\
\text { remission: } 12 \%\end{array}$ & - \\
\hline $\begin{array}{l}\text { Probert et } \\
\text { al }^{32} \text {; Gaya } \\
\text { et al. }{ }^{34}\end{array}$ & $\begin{array}{l}\text { Phase } 4 \text {, multicenter clinical } \\
\text { study }\end{array}$ & $\begin{array}{l}\text { United } \\
\text { Kingdom }\end{array}$ & 205 & $100 \%$ anti-TNF naïve & 66 weeks & $\begin{array}{l}\text { W6 clinical response: } \\
68.8 \% \\
\text { W6 clinical remission: } \\
38.5 \%\end{array}$ & $\begin{array}{l}\text { W54 clinical response: } \\
37.1 \% \\
\text { W54 clinical remission: } \\
30 \% \\
\text { (among initial } \\
\text { responders) }\end{array}$ & - \\
\hline $\begin{array}{l}\text { Bossuyt et } \\
\text { al. }^{37}\end{array}$ & $\begin{array}{l}\text { Phase } 4 \text {, multicenter clinical } \\
\text { study }\end{array}$ & Belgium & 91 & $\begin{array}{l}87 \% \text { anti-TNF naïve } \\
13 \% \text { anti-TNF } \\
\text { experienced } \\
\text { Concomitant IS: } 38 \%\end{array}$ & $\begin{array}{l}\text { Median } 36 \text { weeks (IQR } \\
\text { 12-106) }\end{array}$ & $\begin{array}{l}\text { W14 CS-free } \\
\text { golimumab } \\
\text { continuation: } 43 \%\end{array}$ & $\begin{array}{l}\text { W26 CS-free } \\
\text { golimumab } \\
\text { continuation: } 41 \% \\
\text { W52 CS-free } \\
\text { golimumab } \\
\text { continuation: } 30 \%\end{array}$ & $\begin{array}{l}\text { W14 mucosal healing: } \\
40 \%\end{array}$ \\
\hline
\end{tabular}

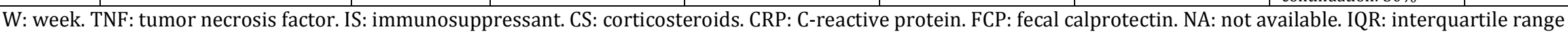

